\title{
ANALYSIS OF THE CURRENT STATE OF INCOME AND EXPENDITURE STRUCTURE OF THE POPULATION IN UKRAINE
}

\author{
Svitlana SLIUSAR ${ }^{1}$ \\ Pereiaslav-Khmelnitskyi State Pedagogical University named after Hryhorii Skovoroda, Ukraine
}

\begin{abstract}
The article is a study of the current state of the income and expenditure structure of the population in Ukraine, in particular, the level of income and expenditure in the context of national integration into the world economy. The purpose of the study in the article is to analyse the current state of the income and expenditure structure of the population in Ukraine in the context of national integration into the world economy. The object of the research is the financial provision of the population of Ukraine; the subject is the dynamics of the structure of incomes and expenditures of the population of Ukraine. Methodology. During the writing of the article, the following research methods are used: the search for available methodological and scientific literature, comparison, clarification of causal relationships, systematization, analysis of documentation and results of researchers' work on the problem of the conducted research and expert evaluation. Results. During the research, it is observed that social security and wages rank one of the most important places in the income structure. So they are stressed. Social security includes pensions and various types of benefits (temporary disability, pregnancy and childbirth, child care up to 3 years of age, caring for a sick child, burial, assistance for disabled people whose income is less than the established limit of low income, etc.). Social security also provides for the provision of assistance in kind (care for the disabled, elderly people in specialized institutions - at boarding houses and at home). In Soviet times, all social payments were made exclusively by the state. It is established that sources of financing social protection services and social security, in accordance with the Budget Code of Ukraine, are state and local budgets. Expenditures of social orientation include expenditures on health care, spiritual and physical development, education, social protection and social security. We consider the actual structure of income of the population. Social payments are second only to wages earned by Ukrainians at the expense of the state budget. Their share accounts for $36.6 \%$ of all incomes. The state budget and other local budgets of Ukraine are by their nature social budgets, and their main expenses are the very different social payments. They include both retirement benefits and scholarships, and various social benefits for the period of temporary disability, and compensation for the cost of services for housing and communal services, etc. On the basis of statistical data, it is established that the minimum wage is not even balanced with the size of the consumer basket, the content of which is very scanty. For example, in developed countries, the size of the consumer basket is the basis for determining the size of the subsistence wage and the minimum wage. According to experts, in order for the minimum wage in Ukraine to cover the costs of the goods and services listed in the consumer basket, it should increase threefold. Reducing the proportion of social benefits in the structure of incomes and increasing the share of social assistance is considered as a positive moment. This indicates an increase in the targeting of social protection measures. The strategy of gradual reduction of the system of privileges will help to improve the system of support of poor people with limited budgetary resources. Practical implications. The author of the article analyses the current state of the structure of incomes and expenditures of the population of Ukraine, taking into account aspects of national integration into the world economy. The author analyses statistics on income and expenditure of the population and international legal acts on social protection of the population. The conclusion is made on the research direction. Value/originality. The article uses the latest statistics concerning the structure of incomes and expenditures of the population of Ukraine and the structure of expenditures from the budget on financing of the population.
\end{abstract}

Key words: economic system, incomes, expenses, social protection, wages, population, dynamics.

JEL Classification: D31, D63, E24, E31, H51, H55

Corresponding author:

${ }^{1}$ Department of Accounting and Taxation, Pereiaslav-Khmelnitskyi State Pedagogical University named after Hryhorii Skovoroda.

E-mail: devko89@ukr.net 


\section{Introduction}

Today, a compliance with international normative legal acts containing the standards of social and economic rights of citizens and regulating the income of the population in Ukraine is somewhat unbalanced. Accordingly, the question of the economic and legal regulation of financial security, the regulation of incomes and expenses of the population is very relevant today for our country. In social income structure, social security and wages take one of the most important places. The main expenses of the population are the expenses on buying goods, paying for services, accumulation in banks for bank deposits. Individual expenses still include deducted personal income taxes.

The purpose of the study is to analyse the current state of the income and expenditure structure of the population in Ukraine in the context of national integration into the world economy. The methodology of the study consists of: search method, comparison, clarification of causal relationships, systematization, analysis of documentation, and results of researchers on the problem of the conducted research and expert assessment. The research in the article has a clear structure and solves the set tasks: the legal basis of financial provision of the population of Ukraine is analysed, in particular, the regulation of the social sphere since it is the most vulnerable and the sphere of wages; sources of financing for the social sphere of the population are determined; the population structure of incomes and expenses for 2017 and dynamics of the previous year are presented; consumer price indexes in 2016-2017 are analysed in the dynamics.

\section{The legal basis of the financial provision of the population of Ukraine}

Since international legal acts are of particular importance for Ukraine, Ukraine's integration into the world economy, globalization processes in the world, and Ukraine's membership in the Council of Europe require adaptation of national legislation to the standards of the European Community, including the rights and freedoms of citizens, the level of their life. Ukraine ratified about 30 conventions of the Council of Europe. The ratification of "European Convention for the Protection of Human Rights and Fundamental Freedoms" and the recognition by Ukraine on its territory of the jurisdiction of the European Court of Human Rights in all matters relating to the interpretation and application of the Convention, requires the direct application of the Convention by courts of general jurisdiction and other entities in our state. The situation regarding implementation of the European Social Charter in Ukraine remains difficult on the part of its actual implementation. Ukraine joined 27 articles and 74 paragraphs of the "Charter" but significant changes in the state of observance of human rights and freedoms, the achievement of European social standards and the quality of life have not taken place yet (Vasylenko, 2017).

At the same time, it is noted that national legislation must rely on the standards of international institutions, in particular, the United Nations and the International Labour Organization. This group of normative legal acts should include the Universal Declaration of Human Rights of 1948, the International Covenant on Economic, Social, and Cultural Rights of 1966, the Convention of the International Labour Organization on Social Protection of 1952, the European Social Charter of 1961, revised in 1996, ILO Convention № 117 "On Basic Aims and Standards of Social Policy", 1962, and other documents ratified by Ukraine, which define the responsibilities of the state in the social sphere. The ILO Convention № 117 guarantees that the state must take all measures to ensure a decent standard of living for citizens, to promote progress in areas such as health care, housing, food security, education, child welfare, the status of women, conditions of labour, remuneration of hired workers and independent producers, protection of migrants' rights, social security, etc. (Budget monitoring, 2014).

In recent years, legislative acts, programs, and other normative documents defining the volumes of expenditure of state and local budgets, in particular, on the financing of the population, were mostly taken without proper consideration of the possibilities of the economy and the population to generate budget revenues. This led to a structural imbalance of public finances, significant (hidden and obvious) deficits of the state budget. The gap between the needs and the actual volumes of budget resources can be overcome by suspending certain regulatory legal acts, the expenses on which are not provided in the budgets or foreseen not in full. This will ensure the necessary financing of urgent social programs and, at the same time, prevent the growth of such debts (Andreyev, 2017).

It is noticed that the legal framework of Ukraine, which defines the state social privileges of citizens and the mechanism of their security and is a regulator of incomes and expenditures of the population, is in an improper condition in relation to European normative documents. Accordingly, there is no single system legal regulation, regulating the entire social sphere in Ukraine. And this fact causes some difficulties.

The laws of Ukraine guarantee the social protection of certain categories of citizens through the provision of benefits and state social support. However, the system of benefits has been proved to be ineffective in providing social protection. That is why in 2002 the Government approved the Strategy for replacing the system of benefits for targeted cash assistance, the main task of which was to increase the targeting of benefits through the ordering, the establishment of a clear accounting of preferential categories of citizens, and the definition of the real size of budget expenditures directed to social 
protection, however for today the implementation of the Strategy for replacing the benefits system targeted cash assistance is suspended (Novikov, 2015). It is also observed that relations in the field of the social partnership are actually regulated by the countless amount of contradictory sub-normative legal acts. The dispersion of the legal and regulatory framework for the financial provision of social protection can be resolved by adopting a document that reflects social interests, regulating social relations in the field of social partnership, guaranteeing the rights and freedoms of citizens, contributing to the establishment of a high level of profitability and social protection of the population in our country. Such a legal act can be the Social Code, which should also determine the procedure for the application of state social standards and norms. It will also solve the problems and inconsistencies in the legal regulation of the financial provision of social protection of the population in the post-crisis economy of Ukraine. The construction of a sustainable social protection system involves a combination of stability, economic growth, a rigorous discipline of deductions, social partnership, state and private forms of social protection, and the integration of social policy objectives into a macroeconomic strategy (Floreskul, 2016).

The sources of financing of social protection and social security services, in accordance with the Budget Code of Ukraine, are state and local budgets. Expenditures of social orientation include expenditures on health care, spiritual and physical development, education, social protection, and social security.

\section{Structure of income and expenditure of the population}

Let us consider the actual structure of income (Table 1). Social payments themselves take second place after wages received by Ukrainians at the expense of the state budget. They take about $36.6 \%$ of all incomes. The state budget and other local budgets of Ukraine are, at bottom of fact, social budgets, and their main expenses are the very different social payments. They include both pensions and scholarships, and various social benefits for the period of temporary disability, and compensation for the cost of services for housing and communal services, etc.

During the second quarter of 2017, the individuals received various social benefits worth 86 billion UAH from the state budget and PF. The wages, taking into account all bonuses and premiums in the structure of incomes, occupy $47.1 \%$ and are one of the main sources of income of Ukrainians (State Statistics Service of Ukraine, 2016).

According to the official data of the State Statistics Service of Ukraine, according to the results of the second quarter of 2017, the total income of the population amounted to 559 billion $\mathrm{UAH}$, although in the per capita calculation it is only about 17 thousand UAH. The amount is small, but it is only official income. For a comparison, ten years ago, according to the results of the first quarter of 2007, the income of Ukrainians per capita amounted to $1522 \mathrm{UAH}$. It turns out that over ten years the income of the population in dollar equivalent has increased in almost 3.2 times. But the needs of the population have probably increased tenfold, although in the distant 2007 people complained as well that the incomes are small (State Statistics Service of Ukraine, 2016).

Table 1

Income and expenditure of the population of Ukraine during the 2nd quarter of 2017, million UAH

\begin{tabular}{|c|c|c|}
\hline Income & 559916 & 100,0 \\
\hline wage & 263508 & 47,1 \\
\hline profit and mixed income & 78072 & 13,9 \\
\hline property income (received) & 13470 & 2,4 \\
\hline $\begin{array}{l}\text { social benefits and other benefits current } \\
\text { transfers }\end{array}$ & 204866 & 36,6 \\
\hline \multicolumn{3}{|l|}{ including: } \\
\hline social assistance & 96666 & 17,3 \\
\hline other current transfers & 23793 & 4,2 \\
\hline social transfers in kind & 84407 & 15,1 \\
\hline Expenses and savings & 559916 & 100,0 \\
\hline purchase of goods and services & 526830 & 94,1 \\
\hline property income (paid) & 6017 & 1,1 \\
\hline $\begin{array}{l}\text { current taxes on income, property and other } \\
\text { current paid transfers }\end{array}$ & 54695 & 9,7 \\
\hline \multicolumn{3}{|l|}{ including: } \\
\hline current taxes on income, property, etc. & 46047 & 8,2 \\
\hline payment to social insurance & 591 & 0,1 \\
\hline other current transfers & 8057 & 1,4 \\
\hline accumulation of non-financial assets & -7257 & $-1,3$ \\
\hline growth of financial assets & -20369 & $-3,6$ \\
\hline \multicolumn{3}{|l|}{ among them: } \\
\hline $\begin{array}{l}\text { growth of money deposits and savings in } \\
\text { securities }\end{array}$ & 29948 & 5,3 \\
\hline saving in foreign currency & -30252 & $-5,4$ \\
\hline$(-)$ received loans except repaid ones $(-)$ & 559 & 0,1 \\
\hline
\end{tabular}

(Data is given without taking into account the temporarily occupied territory of the Autonomous Republic of Crimea, Sevastopol, and a part of the area of the anti-terrorist operation)

Talking about the structure of population expenditure, according to official figures, about $94.1 \%$ of all expenditures of Ukrainians are expenses on purchasing goods and paying for services. If you count on a single resident, then the results of the second quarter of 2017 will reach about $10900 \mathrm{UAH}$. Ten years ago these figures were $1420 \mathrm{UAH}$. It should be noted that in 2007, the share of expenses for the purchase of goods and services in the expenditure of population was $88.36 \%$. The situation has changed. And it has changed in many respects due to the growth of population's savings, especially the placement of money for bank 
deposits. If in 2007 the share of the growth of financial investments amounted to $2.2 \%$ in the expenditure structure of the population, then in the first quarter of 2017 this index was already $7.6 \%$.

It turns out that over the past ten years, despite the crisis and various political cataclysms, the population began to tend to put money on deposit, because the incomes allow individuals to accumulate and accumulate (State Statistics Service of Ukraine, 2016).

Individual expenses still include withholding personal income taxes. At the moment, Ukrainians give in the form of various taxes and fees, about $9.7 \%$ of their expenses to the state, and ten years ago this figure was $8.9 \%$. We can say that the tax burden has increased: the amount of taxes in absolute numbers has even increased and incomes have also increased over the past ten years.

As for other countries and the share of taxes in the structure of the expenditure of individuals, it depends very much on the model of taxation of the country. In the United States, the share of tax payments in the structure of individual expenditures reaches almost 30\% but this is due to the fact that a part of the tax burden of business is switched to individuals. A similar model exists in Sweden and Norway, there is even more share of tax payments in the structure of expenditure. But in Hong Kong the situation is opposite: the share of tax payments in the population is not higher than $4 \%$. Our model of tax sharing between business and individuals is close to the model adopted in Russia and other CIS countries.

Regarding temporal differentiation, the beginning of the year is the most active period of income growth. As a rule, incomes and expenditure of individuals grow to the most at the end of the year. But in summer, expense grows more, as there is the growth of the desire to spend more and more money. The main thing is that this desire could be realized at the expense of previously accumulated income.

\section{Structure of expenditures from the budget on the financing of the population}

According to the data of the State Statistics Committee, expenses of the social direction of the consolidated budget at the beginning of 2017 amounted to 154 billion $\mathrm{UAH}$, which is $13.5 \%$ more than the same indicator of the previous year. The share of expenses on the sociocultural sphere in the consolidated budget amounted to $64.4 \%$ in 2017 , in particular, the share of expenditures on education amounted to $20.9 \%$, health care $-12.2 \%$, social protection and social security $-28.6 \%$. In the period of 2007-2017, the share of expenditures of the consolidated budget of social direction tended to increase (Fig. 1) (State Statistics Service of Ukraine, 2016).

The share of expenditures in the social direction in the state budget amounted to $93.2 \%$ in 2017 , which is 0,5 percentage points more than the same indicator in 2015.

In 2015, this share amounted to $92.7 \%$, which is 1.1 percentage points less than the same indicator in 2014 (it should be noted that in 2007 there was a sharp decline of this indicator to $40.6 \%$, and in 2008 the growth was up to $45.3 \%$, which is explained mainly by a substantial increase in payments for coverage of depreciated monetary savings) (Budget monitoring, 2014-2017).

Local budgets make a much larger share of spending in the socio-cultural field than the state budget. It is explained by the structure of expenditures of local budgets in accordance with the Budget Code of Ukraine. By 2015, this share of local budget expenditures increased by 2.6 percentage points compared to the previous year and amounted to $94.3 \%$ (Budget monitoring, 2016). And in 2016, this share decreased by 1.2 percentage points to $93.1 \%$, which is a positive factor (Law of Ukraine, 2013).

During the period of 2012-2016, there was a tendency to increase the expenditures of social orientation both from the local budget and consolidated and state budgets. But it should be noted that the growth rate of expenditures on social protection of the state budget was lower than the growth rate of expenditures on education, health care, spiritual and physical development in the period of 2005-2009 (exceeding 100\%). In 2008, this rate of growth was the highest among all types of expenditures, which was, as it was already noted, due to a significant increase in payments to cover depreciated cash savings (Budget monitoring, 2014-2015).

Comparing to 2015, in 2016 the growth of expenditures of the state budget in all sectors was observed. The 
Table 2

Expenditures for the social protection and social security (Budget monitoring, 2017)

\begin{tabular}{|l|c|c|c|c|c|}
\hline \multicolumn{1}{|c|}{ Indexes } & \multicolumn{3}{c|}{ Years } \\
\cline { 2 - 6 } & 2013 & 2014 & 2015 & 2016 & 2017 \\
\hline Actual expenditures on social protection and social security & 78775,4 & 104534,9 & 105434,8 & 125306,90 & 145062,40 \\
\hline $\begin{array}{l}\text { The growth rates of the expenditures on social protection } \\
\text { and provision in comparison with the corresponding period } \\
\text { of the last year, in \% }\end{array}$ & 106,3 & 132,7 & 100,9 & 118,8 & 115,8 \\
\hline
\end{tabular}

expenditures of the social budget of the state budget amounted to 287.6 billion UAH, which is 16.4 billion UAH more than activities in 2014 , so there was a $6 \%$ increase. Such a trend has been observed in recent years, spending on social protection and social security is ranked second only after intergovernmental transfers (Budget monitoring, 2016-2017, Kudinova, 2016).

The largest increase in nominal expenditure in 2015 comparing with 2014 was in the following areas [5]: social protection and social security - by 13.3 billion UAH (or by $17.7 \%$ ); nationwide functions - by 6.1 billion UAH (or by $13.8 \%$ ); health care - by 1.5 billion UAH (or by 13,4\%). A significant increase in expenditures on social protection and social security can be explained due to an increase in expenses for the payment of pensions (an increase of 18.7 billion UAH (by $52.1 \%$ ) There was also an influence of a significant increase in expenditures to cover the deficit of the Pension Fund of Ukraine (on 12.8 billion UAH) (State Statistics Service of Ukraine, 2016).

Thus, a significant increase in social expenditures took place in 2016 as a result of the expansion of social guarantees, especially the minimum wage and minimum living wage for able-bodied persons in 2016 compared to 2015 increased by $63.7 \%$.

\section{Equalization of wages and social standards to the consumer price index}

As for wages, at the beginning of 2017, the minimum wage was $3200 \mathrm{UAH}$ (in accordance with the Law

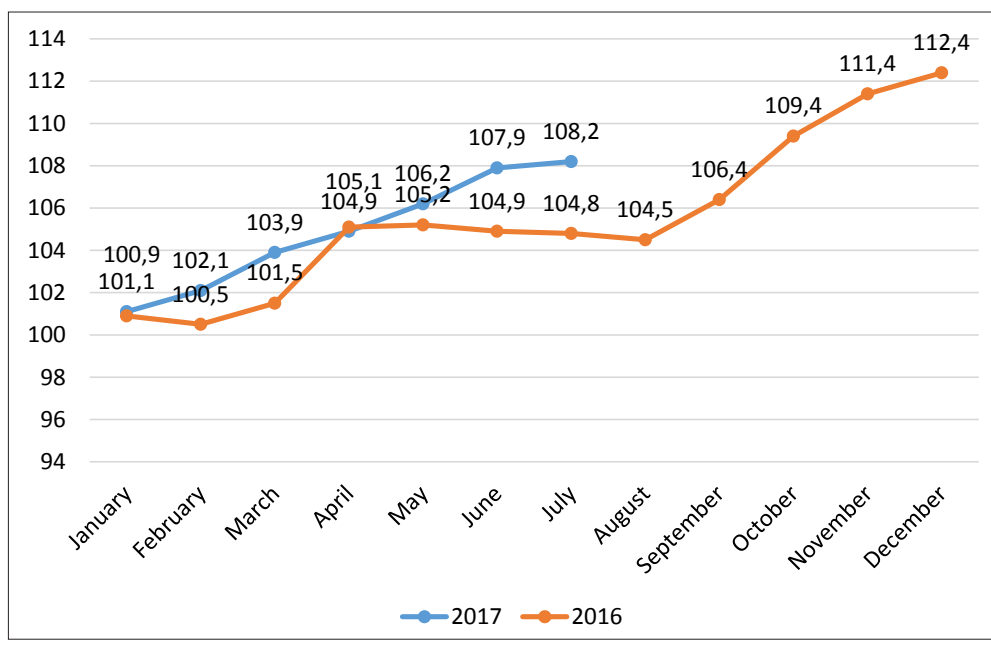

Fig. 2. Consumer price index from 2016 to 2017 of Ukraine "On State Budget of Ukraine for 2017") and prevailed over the average minimum living wage by $3.6 \%$. In fact, this is considered as a positive factor, although the advance of the size of the minimum wage above the average minimum living wage will not lead to a balance between the wage fund and social benefits. As it was evidenced by the experience of European countries, the minimum wage must exceed the minimum living wage by at least 2.5 times. It should also be noted that the growth of the minimum wage, as well as the total size of the minimum wage, is completely "torn off" from the real economic situation in the country and actually makes it impossible for the individual to stay at an adequate level.

In 2017, social standards and guarantees were raised at a higher pace than the inflation rate. The average minimum living wage per person, the minimum wage, and the minimum pension increased by $7.4 \%$. At the same time, the consumer price index for 2017 amounted to $100.5 \%$. Consumer price indices for 2016-2017 are shown in Fig. 2.

According to the rating agency Standard \& Poor's, the inflation rate in Ukraine in 2016 was fixed at $99.9 \%$. It is noted that in coming years - 2018 and 2019 - the World Bank forecasts inflation at the level of $95-99 \%$ (Budget monitoring, 2017). Thus, the increase of the minimum pension in Ukraine is quite unlikely to be felt by pensioners. Talking about wages, its growth almost by $5 \%$ is unlikely to block the projected inflation rate. It is said that the growth of prices for goods and services in the country is much faster than the growth of the minimum, guaranteed by the state, incomes of the population.

\section{Conclusions}

Thus, social security and wages take one of the most important places in the structure of income. Social security includes pensions and various types of benefits (temporary disability, pregnancy and childbirth, child care up to 3 years of age, caring for a sick child, burial, assistance for disabled people whose income is less than the established limit for low income, etc.). Social security also provides the assistance in kind (care for the disabled, elderly people in specialized 
institutions - at boarding houses and at home). In Soviet times, all social payments were made exclusively by the state. As for wages, the minimum wage is not even balanced with the size of the consumer basket, the content of which is too scanty. For example, in developed countries, the size of the consumer basket is the basis for determining the size of the minimum living wage and the minimum wage. According to experts, in order for the minimum wage in Ukraine to cover the costs of the goods and services listed in the consumer basket, it should increase threefold. Reducing the proportion of social benefits in the structure of incomes and increasing the share of social assistance is considered as a positive moment. This indicates an increase in the targeting of social protection measures. The strategy of gradual reduction of the system of privileges will help to improve the system of support of poor people with limited budgetary resources.

\section{References:}

Andreyev, V. S. (2017). Social policy, 1:315.

Budget monitoring: Analysis of budget execution for (2014). Electronic resource, Liga Law: Legal portal. - Access mode: http://www.ibser.org.ua/sites/default/files/kv_iv_2014_monitoring_ukr.pdf

Budget monitoring: Analysis of budget execution for $(\overline{2} 015)$. Electronic resource, Liga Law: Legal portal. - Access mode: http://www.ibser.org.ua/sites/default/files/kv_iv_2015_monitoring_ukr.pdf

Budget monitoring: Analysis of budget execution for $(\overline{2016})$. Electronic resource, Liga Law: Legal portal. - Access mode: http://www.ibser.org.ua/sites/default/files/kv_iii_2016_monitoring_ukr_0.pdf

Budget monitoring: Analysis of budget execution for $(\overline{2} 01 \overline{7})$. Electronic resource, Liga Law: Legal portal. - Access mode: http://www.ibser.org.ua/sites/default/files/kv_i_2017_monitoring_ukr_1.pdf

Vasilik, O. D. (2014). Budget system of Ukraine / K.: Center of Native Literature, 355 p.

Vasylenko, P. (2017). How is the European Social Charter executed (revised): Social policy. -48 p.

State Statistics Service of Ukraine (2016). Electronic resource, Liga Law: Legal portal. - Access mode: http://www.ukrstat.gov.ua

Law of Ukraine «On State Social Assistance to Persons Without Retirement and Disabled Persons» (2013). Document 1727-15, valid, basis 231-18 / Information from the Verkhovna Rada of Ukraine (VVR), № 33-34, Art. 404

Karpenko, A. I. Problems of organization of financing of social sphere in Ukraine (2015). Electronic resource, Liga Law: Legal portal. - Access mode: http://intkonf.org/karpenko-ai- problemi-organizatsiyifinansuvannyasotsialnoyi-sferi-v-ukrayini.html.pdf

Convention of the International Labor Organization № 130 (1969). Electronic resource, Liga Law: Legal portal. Access mode: http://zakon.rada.gov.ua/cgi-bin/laws/main.cgi?page=7\&amp;user=c395

Kudinova, M. M., Varuk, V. V. (2016). Problems of financing of social protection of the population in Ukraine. Global and national problems of economy. $-215 \mathrm{p}$.

Novikov, V. M. (2015). Social transformations: international and national experience: monograph - K.: NAS of Ukraine: Institute of Economics of the National Academy of Sciences of Ukraine. - $253 \mathrm{p}$.

Floreskul, N. (2016). Legal Regulation of Financial Provision of Social Protection of Population. Bulletin of the KNETU, № $22-144$ p.

\section{Светлана СЛЮСАР, Ярослав ПОНОМАРЕНКО}

\section{АНАЛИЗ СТРУКТУРЫ ДОХОДОВ И РАСХОДОВ НАСЕЛЕНИЯ УКРАИНЫ}

Аннотация. Статья является исследованием современного состояния структуры доходов и расходов населения в Украине, в том числе уровня доходов и расходов в контексте национальной интеграции в мировой экономики. Целью исследования является проведение анализа современного состояния структуры доходов и расходов населения в Украине в контексте национальной интеграции в мировой экономики. Объектом исследования является финансовое обеспечение населения Украины, предметом динамика структуры доходов и расходов населения Украины. Методология. Во время написания статьи использованы следующие методы исследования: поисковый по имеющейся методической и научной литературе, сравнение, выяснение причинно-следственных связей, систематизация, анализ документации и результатов деятельности исследователей по проблеме проведенного исследования и экспертная оценка. Результаты исследования. В ходе исследования замечено, что в структуре доходов населения социальное обеспечение и заработная плата занимают одно из самых важных мест. На них и сделан упор. Социальное обеспечение включает в себя пенсии и различные виды пособий (по временной потере трудоспособности, по беременности и родам, по уходу за ребенком до 3 лет, по уходу за больным ребенком, на погребение, помощь нетрудоспособным лицам, доход которых меньше установленной границы малообеспеченности, и тому подобное). Социальное обеспечение предусматривает также предоставление помощи в натуральном 
виде (обслуживание инвалидов, людей пожилого возраста в специализированных учреждениях домах-интернатах и на дому). В советское время все социальные выплаты осуществляло исключительно государство. Установлено, что источниками финансирования услуг социальной защиты и социального обеспечения, согласно Бюджетного кодекса Украины, являются государственный и местный бюджеты. К расходам социальной направленности относятся расходы на здравоохранение, духовное и физическое развитие, образование, социальную защиту и социальное обеспечение. Нами рассмотрены собственно структуру доходов населения. Социальные выплаты занимают второе место после заработной платы, которые получают украинцы за счет госбюджета. На их долю приходится 36,6 \% всех доходов населения. Госбюджет и другие местные бюджеты Украины по своей сути являются социальными бюджетами, и главные их затраты - это именно различные социальные выплаты. Они включают и пенсионные выплаты и стипендии, различные социальные пособия на период временной нетрудоспособности, и компенсации стоимости услуг ЖКХ. На базе статистических данных установлено, что минимальная заработная плата даже не балансируется с размером потребительской корзины, содержимое которого слишком мизерный. Для примера, в развитых странах именно размер потребительской корзины является базой для определения размера прожиточного минимума и минимальной заработной платы. По свидетельствам экспертов, для того, чтобы минимальная заработная плата в Украине покрывала расходы на перечисленные в потребительской корзине необходимые товары и услуги, размер ее должен вырасти втрое. Уменьшение удельного веса социальных льгот в структуре доходов населения и роста доли социальной помощи считают положительным моментом. Это свидетельствует об усилении адресности мер социальной защиты. Стратегия постепенного сокращения системы льгот будет способствовать совершенствованию системы поддержки бедного населения, которое имеет ограниченные бюджетные ресурсы. Практическое значение. Авторами статьи проведен анализ современного состояния структуры доходов и расходов населения Украины, учитывая аспекты национальной интеграции в мировой экономики. Авторами проанализированы статистические данные относительно доходов и расходов населения и международно-правовые акты по социальной защите населения. Сделан собственный вывод по направлению исследования. Значение/оригинальность. В статье использованы последние статистические данные относительно структуры доходов и расходов населения Украины и структуры расходов бюджета по финансированию населения. 